\title{
"Climate change might have caused our small harvest": indigenous vulnerability, livelihoods, and environmental changes in lowland and high jungle indigenous communities in Peru
}

\author{
Dafne E. Lastra Landa ${ }^{1}$ (D) . Claudia V. Grados Bueno ${ }^{2}$ (D)
}

Accepted: 2 September 2021 / Published online: 15 September 2021

(c) AESS 2021

\begin{abstract}
The purpose of this article is to analyze how indigenous livelihoods are challenged by the global phenomenon of climate change while paying particular attention to how historically shaped, non-climatic factors influence how climate change is experienced in the Peruvian Amazon. In this sense, we will address indigenous people's lived experiences of climate variations using a theoretical framework based on concepts of vulnerability. Methodologically, we draw on both a recent literature review and fieldwork conducted during 2015 and 2016 with two Kukama Kukamiria communities in Loreto (low jungle) and three Ashaninka communities in Junín (high jungle). After describing our theoretical framework and qualitative methods, we discuss the economic history of the addressed areas and show how non-climatic factors, such as colonialism, influence these communities' experiences. This context allows us to better understand indigenous people's experience of seasonal variations, precipitations and climatic events, its effect on their livelihoods, and their adaptive strategies in response to challenges imposed by climate unpredictability and broader transformations in their territories. Our conclusions are twofold: (a) addressing climate change must incorporate multiple temporal and spatial scales and (b) non-climatic factors are integral to understanding the role of climate change vulnerability of indigenous population.
\end{abstract}

Keywords Climate change $\cdot$ Vulnerability $\cdot$ Livelihoods $\cdot$ Indigenous people $\cdot$ Amazon $\cdot$ Peru

\section{Introduction: climate change in Amazonia}

In recent decades, the Amazon has suffered significant environmental changes due to the effects of anthropogenic activities. In particular, climate change, deforestation, and the contamination of soils and water sources (e.g., rivers and lakes) have had major impacts on the life, health, and food security of local populations in general and indigenous people in particular (Echeverri 2009; Hofmeijer et al. 2013; Williams 2012).

Claudia V. Grados Bueno

claudia.grados@pucp.pe

Dafne E. Lastra Landa

DEL60@pitt.edu

1 Anthropology Department, University of Pittsburgh, Pittsburgh, PA, USA

2 Social Science Department, Pontificia Universidad Católica del Perú, Lima, Peru
People who live in the Amazon organize their livelihood activities according to two annual phases or seasons: one dry season with low water levels and another rainy (or wet) season with high water levels (Sherman et al. 2015, 2051). Those living in the Amazonian floodplains are closely connected to this hydrological regime (Pinho \& Orlove in Tomasella et al. 2013, 726). Agriculture and fishing are two primary activities that depend upon the water cycles, water flows, and flood pulses (Sherman et al. 2015, 2051). Other relevant activities include hunting, horticulture, and foraging (Lu 2007, 596).

Meteorological studies indicate that there are permanent increases and decreases in river flow cycles associated with precipitation in the Amazonian region. These cycles facilitate the annual flooding of riverbanks that are necessary for the reproduction of certain aquatic and flora species. However, two of the worst floods in the last century occurred in 2011 and 2012. Thus, rises in river flow and floods are among the most critical effects of climate change in this region, as well as one of the most rapidly perceived changes during this period (Espinosa et al. 2014; 
Espinoza et al. 2014; Fundación Manuel J. Bustamante de la Fuente 2010). Scholars have also indicated that since the mid-1990s, the Peruvian Amazonian region has registered a range of anomalies and extreme climatic events, such as the droughts of 1995, 1998, 2005, and 2010 (Espinoza et al. 2014, 3-5). Studies also mention a projected temperature increase between $0.5^{\circ} \mathrm{C}$ and $1.8^{\circ} \mathrm{C}$ by 2020 and between $1.6^{\circ} \mathrm{C}$ and $7.5^{\circ} \mathrm{C}$ by 2080 (Fundación Manuel J. Bustamante De la Fuente 2010). Among the main consequences of such an increase are the rise of sediments and wildfires, deaths of trees, as well as droughts and floods, many of which have already occurred (Solomon et al. 2007).

In Peru, many global climate changes have already been identified by indigenous peoples. Since their livelihoods directly depend on the environmental resources affected by such climatic events and stimuli, these changes increase their vulnerability (Sherman et al. 2015, 2051). However, nonclimatic factors, such as colonization or the extraction of oil and rubber, have also been crucial in shaping indigenous experiences of climate variation.

The purpose of this article is therefore to analyze how indigenous livelihoods are challenged by climate change, which is a global phenomenon, while also accounting for the specific influence of historical, non-climatic factors with both regional and local manifestations. This perspective enhances our analysis of large-scale meteorological changes and weather patterns in relation to indigenous people's lived experiences. We consider how climate variations such as seasonal variations, precipitation patterns, and floods influence the vulnerability and the livelihoods of the indigenous populations-specifically the Kukama Kukamiria and Ashaninka ethnic groups - with whom we have worked. Our analysis brings insights about the situation of indigenous communities facing the effects of climate change in the global south and thus contributes to an expanding scholarship on vulnerability, adaptation and climate change, and indigenous environmental studies.

In the following sections, we begin by describing our framework and present our methodological approach. We then briefly describe the economic history of the Junín region (in the high jungle) and Loreto region (in the low jungle) where we conducted our research, highlighting the processes and non-climatic factors that have influenced Ashaninka and Kukama Kukamiria people's vulnerability. Finally, we discuss how community members identify and experience climate change manifestations in their territories according to the three dimensions of vulnerability: exposure, sensitivity, and adaptive capacity. Our intention is to begin a dialogue comparing the impact of climate change on the two different regions mentioned above: Junín and Loreto. We end with the two following conclusions: first, any effort to address climate change and its effects on indigenous livelihoods must incorporate an analysis of the multiple scales in which it manifests. Second, understanding the extent to which indigenous livelihoods are made vulnerable must also address the role of non-climatic factors in exacerbating the effects of climate change.

\section{Theoretical framework: vulnerable contexts, adaptation, and resilience}

This article draws on the vulnerability framework and how this affects the livelihoods ${ }^{1}$ of indigenous communities in their everyday lives (Hofmeijer et al. 2013, 959; Michetti and Ghinoi 2020). Here, we understand vulnerability as a process as much as an outcome that shows the latent or potential damage provoked by different stimuli or changes in a specific socioecological system (Sherman et al. 2015). Adger (2006) defines vulnerability as "the state of susceptibility to harm from exposure to stresses associated with environmental and social change and from the absence of capacity to adapt" (268). As other studies also show, vulnerability has three connected dimensions (Adger 2006; Pelling 2011; Sherman et al. 2015; IPCC, 2008 in Wilson 2014), which are differentiated in the following way:

a) Exposure refers to environmental and sociopolitical stimuli or stress experienced by a system (Adger 2006, 270; Pelling 2011, 36). It includes features such as proximity, magnitude, frequency, or duration (Burton et al., 1993 in Adger 2006, 270). For example, a community is exposed to a flood and its characteristics.

b) Sensitivity addresses the propensity of a socioecological system to suffer harm, modifications, or change (Adger 2006, 270; Pelling 2011, 36). For example, an exposure to something leads to short or long-term changes to community livelihoods.

c) Adaptive capacity refers to how a system, in this case a community, adjusts to consequences of exposure and sensitivity while also taking advantage of new opportunities. $^{2}$ The access to and the implementation of adaptive capacities depend on the differentiation in the distribu-

\footnotetext{
1 According to Bebbington (1999), livelihoods are a set of resources necessary to meet needs (material and experiential). They could be natural resources, but also include income or capital, products from the market, or others (2021-2022).

2 Adaptation has been addressed in two different ways: as a dimension of vulnerability, as adaptive capacity (Adger 2006), and as its inverse (in Pelling 2011, 35). In the former case, adaptation is understood as "the adjustments in natural or human systems in response to actual or expected climatic stimuli or their effects" (Pelling 2011, 34; Wilson 2014,87). In this paper, we will use the former definition.
} 
tion of resources (Hofmeijer et al. 2013, 3; Michetti and Ghinoi 2020, 292; Ford \& Smit 2004 in Sherman et al. 2015, 2052; Zavaleta et al. 2018, 3) and the possibility of reducing exposure and sensitivity (Pelling 2011,36).

Vulnerability studies have emphasized the adaptation and resilience that indigenous communities develop to face climate and environmental changes. In this sense, adaptation can be spontaneous or planned; it occurs at multiple, interacting scales (Wilson 2014, 87); and it is both a process and a product of social relations (Pelling 2011, 85). Anthropological studies of climate change have underscored, in particular, the importance of adaptation as a multi-scalar process. Drawing on Roncoli (2006), Susan Crate argues that using a political ecology approach to adaptation allows us to see this as not just an event of local communities seeking to reorganize to face unprecedented change, but how it constitutes an ongoing, multi-scalar, multitemporal, and multistakeholder process (2011, 187).

Although adaptation and resilience are usually discussed as interrelated factors, and are often employed in vulnerability studies, resilience is not equal to adaptation (Pelling 2011, 66). Resilience is defined as "the degree of elasticity in a system, its ability to rebound or bounce back after experiencing some stress or shock. It is indicated by the degree of flexibility and persistence of particular functions" (Pelling 2011, 66). Focusing on human populations, resilience can be understood as "the ability of groups to tolerate and respond to environmental and socio-economic constraints through adaptive strategies" (Bradley and Grainger 2004 in Hoffman and Oliver-Smith 2020, 5). As Adger indicates, interdisciplinary understandings of vulnerability and resilience demonstrate that resilient ecosystems and resilient societies can cope with both physical and sociopolitical stresses (2006, 278).

One of the main critiques of the vulnerability framework is its use of the concept only from a risk and hazard perspective, which measures vulnerability as the difference between biophysical risk factors and their potential loss (Eakin and Luers, 2006 in Wilson 2014, 88) without considering historical, social, and political contextual factors (Oliver-Smith 2013, 277-278). Political ecology and ecological resilience approaches, conversely, acknowledge that humans constantly interact with the biophysical environment in socioecological systems, and therefore trace the effects of social inequalities in populations' differential exposures to climate change (Eakin and Luers, 2006 in Wilson 2014, 88). These studies tend to discuss how exposure develops according to climatic and non-climatic factors that impact people's experiences and responses according to different historical and socioeconomic backgrounds.

Despite critiques to these approaches ${ }^{3}$ vulnerability and resilience studies have provided important insights regarding how communities' adaptation to climate change is not just a function of technical solutions, and how the social vulnerability of some groups is structural, entrenched with poverty, racism, and colonialism, and not an outcome of their adaptive failure (Oliver-Smith 2013, 278). Human adaptation is thus influenced by sociocultural relationships, assets, and capitals, all important factors for accessing to resources in times of stress (Crane et al. 2010, Roncoli et al. 2009 in Crate 2011, 180), as we discuss in the following sections.

Non-climatic factors can be associated with global processes in cultural, socioeconomic, political, institutional, and environmental levels (Adger 2006, 87; Hofmeijer et al. 2013, 970, 974; Michetti and Ghinoi 2020, 291; Sherman et al. 2015, 2051; Zavaleta et al. 2018, 24). Non-climatic factors can influence the sensitivity of communities (Zavaleta et al. 2018,4) as they constitute "multiple stressors" that interact with risks at multiple spatial and temporal scales (Smit \& Wandel 2006 in Sherman et al. 2015, 2052; Zavaleta et al. 2018, 3). A similar concept, double exposure, indexes the joint effects of globalization and climate change which generate different sets of winners and losers ( $\mathrm{O}^{\prime}$ Brien and Leichenko 2000, 221).

One of the crucial non-climatic factors analyzed in anthropology and indigenous studies of climate change is colonialism and its intrinsic relation to the resource extraction of oil, timber, and other fuels (O'Reilly et al. 2020, 19; Whyte 2017, 2), as well as land grabbing, deforestation (A. J. Bebbington and Batterbury 2001), and development interventions (Hoffman and Oliver-Smith 2020, 5) driven by states and private corporations. As indigenous scholars argue, vulnerability is an intensification of colonially induced environmental changes or an intensification of ongoing colonialist, capitalist practices (Whyte 2017, 2). Both anthropological and indigenous environmental studies have highlighted the links between settler colonialism and vulnerability and drawn attention to the role that political and historical context plays in an unequal scenario where indigenous people not only are more exposed to negative events (Crate and Nuttall 2016; Whyte 2017, 4), but also have seen their adaptation strategies altered and undermined by different types of interventions (Oliver-Smith 2013, 5). As our case studies show, indigenous livelihoods

\footnotetext{
${ }^{3}$ Social scientists, and anthropologists in particular, have questioned the emphasis that a resilience framework puts on physical systems and predictive models when approaching climate change and its effects (Crate 2011, 186). Another important critique is that when applied, resilience has often served the needs of outside organizations more than local communities (Crate 2011; Orlove 2009).
} 

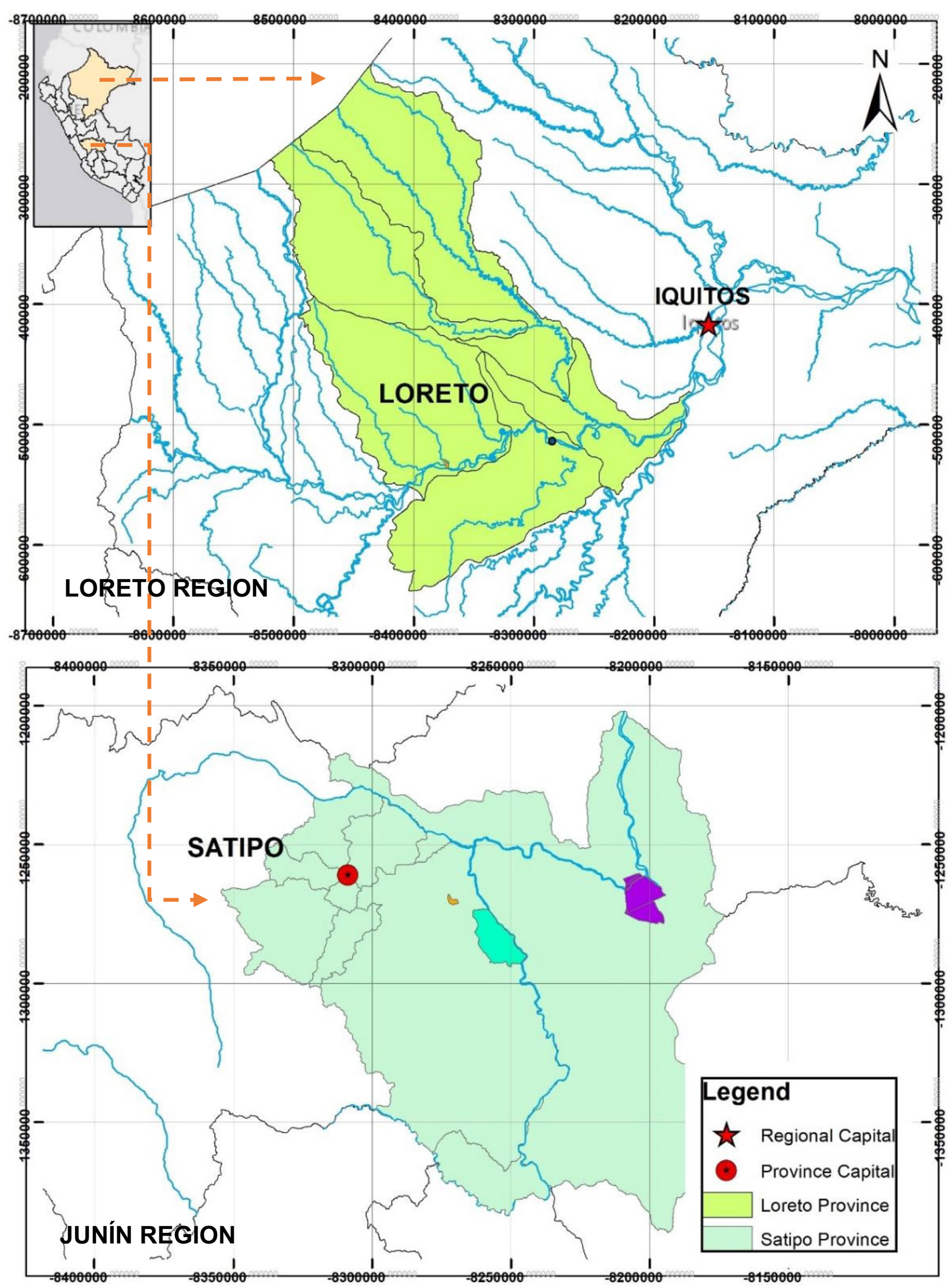
४Fig. 1 Map of research areas in Junín and Loreto. Elaborated by José Víctor Gonzáles Avendaño

are intertwined with extractive industries to various degrees (Espinosa 2019, 2020). We discuss these entanglements in relation to the historical background of the Ashaninka and Kukama Kukamiria communities in the "Historical background: non-climatic factors shaping sensitivity and adaptation" section.

\section{Methodology}

The research on which this article is based is part of a larger project titled the "Impact of environmental changes in indigenous communities of the Peruvian Amazon: the effects of climate change and pollution on indigenous communities of low forest (Loreto) and high forest (Junín)," funded by the Pontifical Catholic University of Peru. ${ }^{4}$ One component of the project was an academic and non-academic literature review on the effects of climate change in the Amazon region with an emphasis on indigenous peoples, the processes of change and transformations that native communities are experiencing, and reports from state entities about oil spills in one of these regions.

Another important component of the project was the collection of data from indigenous communities. Fieldwork was carried out for approximately two months, one in 2015 and another in 2016, with two simultaneous visits to a region of high jungle (Junín) and one of low jungle (Loreto). Both were visited during the dry season (May-August) and wet season (January-February) to better understand climate variability between both periods. The villages visited in Junín belong to the Ashaninka and those in Loreto to the Kukama Kukamiria ethnic groups.

Although the entire Amazonian region is relevant to this study, we focus on the Peruvian Amazon for its diversity of ecosystems and ethnic groups. Depending on the specific location, different economic and political processes have shaped the lives of Ashaninka and Kukama Kukamiria families. It was important for the project to avoid overgeneralizations and try to understand the specific impacts of

\footnotetext{
${ }^{4}$ The project-classified as 2015-3-0029 / 000,000,000,000,191was overseen by Professor Oscar Espinosa de Rivero from the department of Social Sciences. Dafne Lastra Landa and Claudia Grados Bueno coordinated and oversaw both the fieldwork and systematization of data in Junín and Loreto respectively. Fieldwork was carried out by Dafne Lastra Landa (anthropologist), Víctor Ramos Abenzur (mechanical engineer), Meredith Castro Ríos (anthropologist), Blanca Álvarez Becerra (biologist), Gabriela Gonzáles Malca (geographer), Roxana Gastelú Jiménez (anthropologist), and Guillermo Peláez Cotrina (anthropologist). The systematization of the information also included the support of Eduardo Pacheco Riquelme (anthropologist).
}

climate change on two different regions: high jungle (Junín) and low jungle (Loreto). Both represent different socioecological systems and were selected for the purpose of comparing their unique natural conditions ${ }^{5}$ and socioeconomic histories, which are explained in the "Historical background: non-climatic factors shaping sensitivity and adaptation" section. The regions ${ }^{6}$ of the study are represented in Fig. 1, and more details are presented in Appendix 1.

As is portrayed in Fig. 2, in Loreto research was carried out in two Kukama Kukamiria villages named Atenas and Cuninico, both located on the low Marañón River basin in the province of Loreto, in the region of the same name. Atenas is located on the right bank of the river in the Parinari district, with a population of 158 people organized in 40 families. It is located at a higher altitude, which has allowed it to resist flooding. Cuninico is located at a lower level in the Urarinas district and in 2014 experienced an oil spill in the branch of the river that supplied the community with water. Cuninico's population is 585 people organized in 156 families. Fieldwork was possible with prior coordination with the Kukama Kukamiria female federation "Huaynakana Kamatahuara Kana" whose leaders connected us with Cuninico's authorities.

In the region of Junín, fieldwork was carried out in three Ashaninka villages: Cheni, Alto Camonashari, and Potsoteni, located in the Tambo and Ene river basins in the province of Satipo (Fig. 3). Cheni is located on the right bank of the Tambo River in the district of Río Tambo, with an estimated population of 865 people organized in 165 families. Alto Camonashari is located in the district of Mazamari, with a population of 200 people organized in 28 families. Potsoteni is located on the left bank of the Ene River in the district of Pangoa and has a population of approximately 1,000 people organized in 200 families. These villages were visited by the research team thanks to prior coordination with two regional indigenous organizations: the "Central Ashaninka del Río Tambo" (CART), and the "Central Ashaninka del Río Ene" (CARE).

Access to all the villages - with the exception of Alto Camonashari, which requires a 5 -h drive from Satipo

\footnotetext{
5 The high jungle is located on the eastern flank of the Peruvian Andes. It is comprised by a set of forest covered mountains, and its altitude starts at 600 and reach $3,600 \mathrm{~m}$ above sea level. The low jungle, also known as the tropical amazon jungle, is not located in the Andes. It is characterized by a high biodiversity and the existence of two main types of lands: floodplains and non-floodable land (Ministry of Environment 2018, 25).

6 The term refers to the administrative division of Peru in 25 regions, each one subdivided in provinces, and each province conformed by multiple districts. In this case, the province where we conducted fieldwork has the same name as the region: Loreto, while in the region of Junín, the province involved was Satipo.
} 


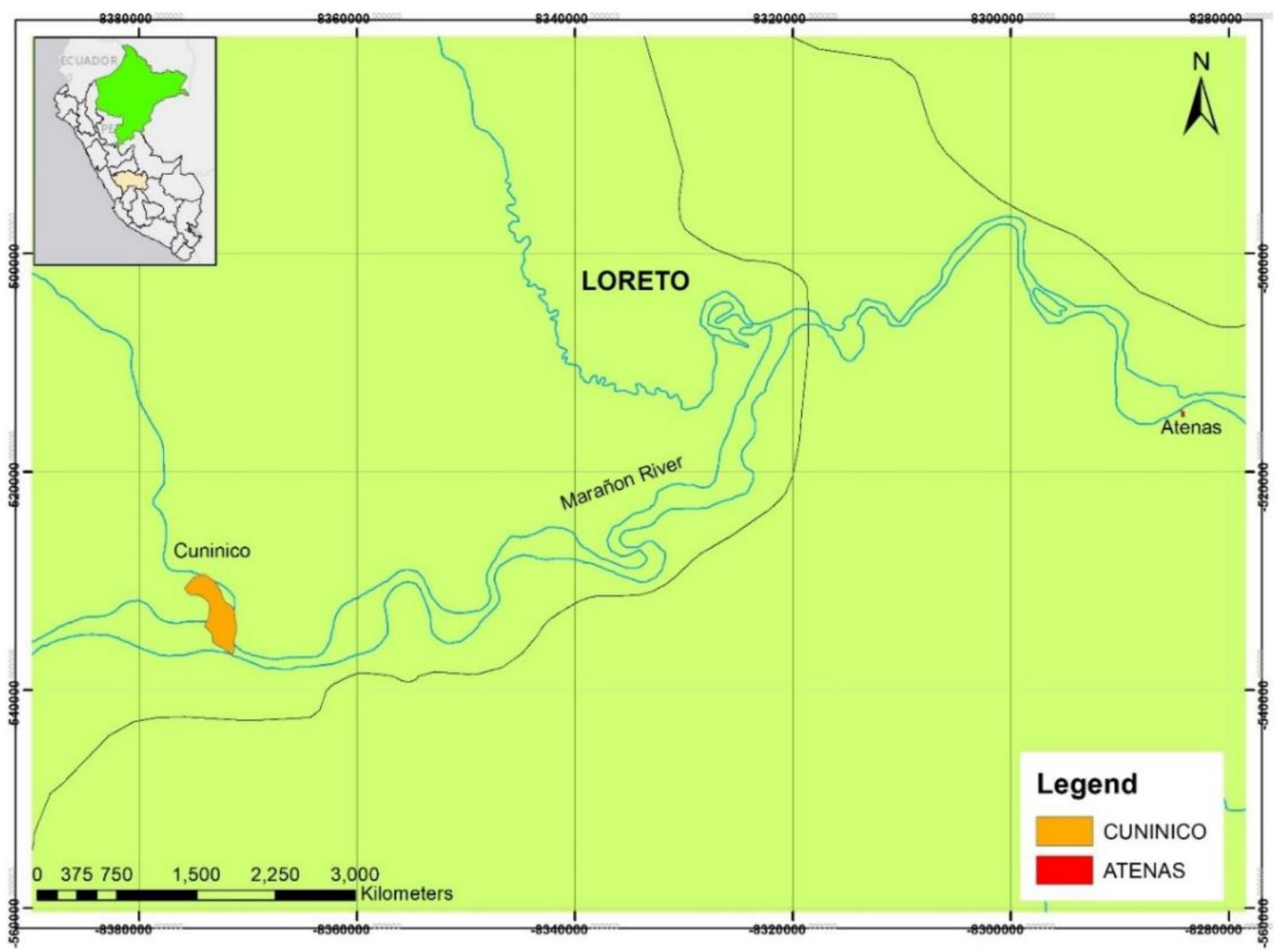

Fig. 2 Map of the communities visited in Loreto Province-Loreto Region. Elaborated by José Víctor Gonzáles Avendaño

City-is by boat and can take up to $4 \mathrm{~h}$ in the case of Junín and $9 \mathrm{~h}$ in Loreto.

Our methodology was qualitative, involving 168 interviews with community members, community leaders and authorities; informal conversations, 14 participatory workshops to map out the communities' resources, the location of water sources, farmlands, fishing and hunting zones, and participant observation of the daily routines and economic activities (fishing and planting farms) of 38 families in the communities of Cheni, Atenas and Cuninico (see Appendix 2).

Using a qualitative approach allowed us to understand indigenous population's experiences with climate change through their daily practices. Although we understand that anthropogenic climate change is a global problem, it manifests at the local level, necessitating research at different scales. Understanding the lived experiences of indigenous people facing the effects of climate change implies a holistic approach to analyzing the vulnerability of socioecological systems (Turner 2003 in Adger 2006, 273), as we mentioned in the "Theoretical framework: vulnerable contexts, adaptation, and resilience" section. This brings to the center how both climatic and non-climatic factors shape the social vulnerability, adaptation, and resilience of Ashaninka and Kukama Kukamiria people to different processes of economic extraction and resource exploitation, as we describe in the next section.

\section{Historical background: non-climatic factors shaping sensitivity and adaptation}

Peruvian indigenous people, including the Ashaninka who live in Junín and the Kukama Kukamiria who live in Loreto, have been subjected to economic, social, and cultural changes shaped by settler colonialism, its practices, and the subsequent exposure to economic markets and increasing contact with non-indigenous populations since the sixteenth century. Both ethnic groups have been historically subordinated by different actors, changing their social organization 


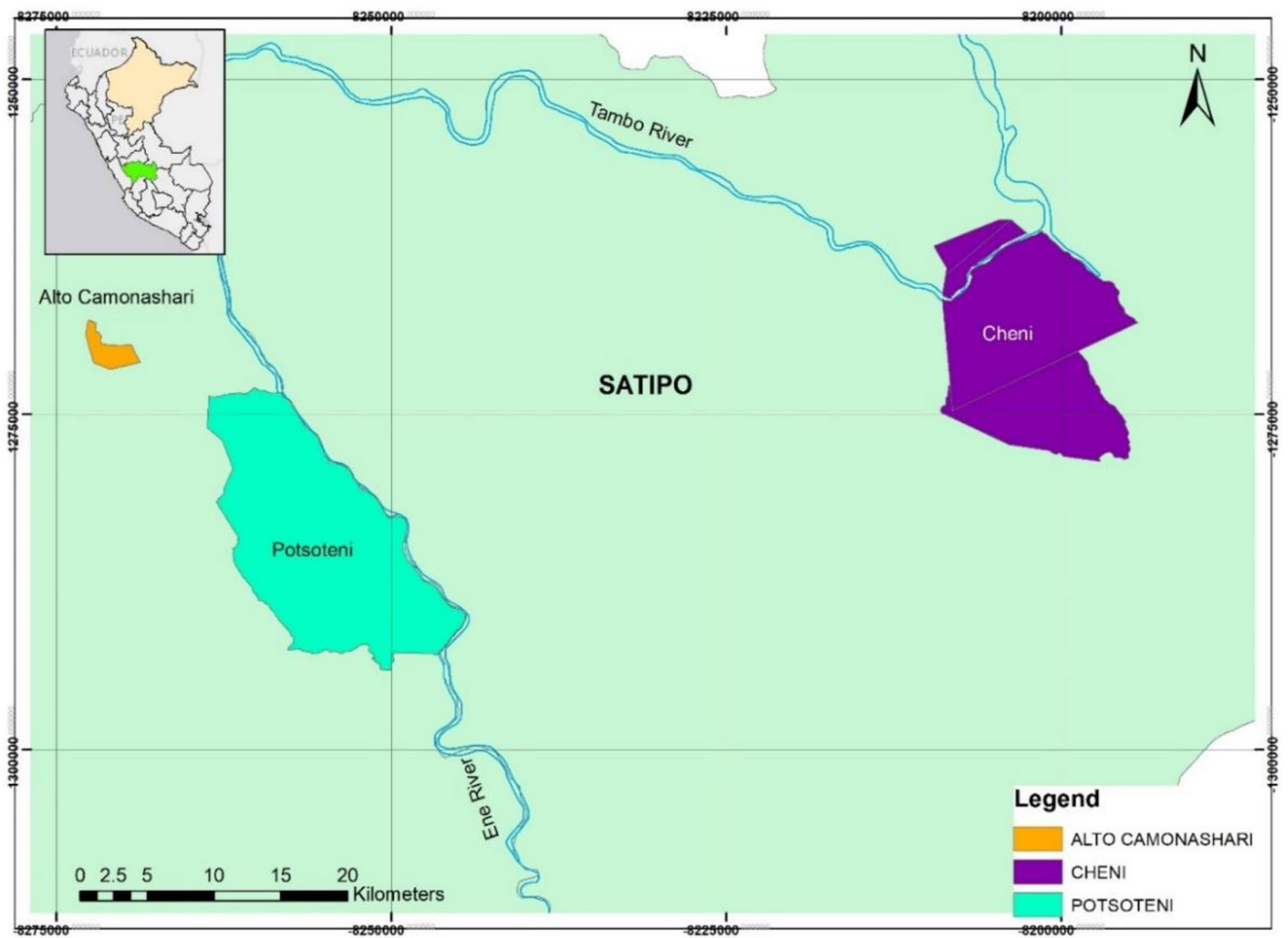

Fig. 3 Map of the communities visited in Satipo Province-Junín Region. Elaborated by José Víctor Gonzáles Avendaño

and mobility. Their current social and economic organization is the result of historical processes that have influenced their relationship with the territory, resources, the state, and the market. In this section, we describe key historical and economic events that have marked the Ashaninka and Kukama Kukamiria ethnic groups. It is crucial to understand how their vulnerability to contemporary environmental changes is tied to colonialism and its practices, as well as to economic extractive cycles, both of which constitute nonclimatic factors.

Ethnohistorians and anthropologists suggest that the processes of spontaneous and state-sponsored colonization of the Amazonian region have been influenced by an underlying Eurocentric colonial gaze (Cipolletti 2017; Pau 2019,79). As Michael Taussig (1986) argues, the creation of a social hierarchical order subordinating native populations in the New World was deeply intertwined with the occupation of their territories and the exploitation of resources. Colonial hegemony both informed and was informed by empire-building processes between the sixteenth and late eighteenth centuries and by nation-building projects seeking the integration of the Amazonian region into national society during the nineteenth and twentieth centuries.

Ethnohistorical analyses of colonialism and its impact on indigenous populations in Peru have underscored how, despite their surviving violence and epidemic diseases, many indigenous people lost their political and economic autonomy by being forcedly relocated and conscripted into the main workforce for mineral extraction, agricultural, and livestock activities. Between 1535 and 1820, for example, the Kukama Kukamiria provided significant labor and domestic service to missionaries in exchange for education and protection from Spanish colonial administrators (Agüero 1994, 54).

Two main historical events, however, influenced the Ashaninka and Kukama Kukamiria's economic participation during the late nineteenth and early twentieth century, marking their history and collective memory: state-sponsored projects of European colonization, and the rubber extraction boom.

Unlike Loreto, coffee production was the main economic activity in Junín at the turn of the twentieth century. The 
state-sponsored process of European colonization into the central Amazonian region-including Junín-was a violent process through which the Ashaninka became the main workforce in agricultural and livestock activities and in timber extraction through a system of forced labor, a form of indebted peonage known as sistema de habilitación y enganche (Espinosa 2016; García Jordán 2015). In Loreto and adjacent areas, the extraction of rubber, driven by international demand, constituted a decisive process that transformed the region both socially and economically. ${ }^{7}$ Violent and coercive methods of labor exploitation used upon indigenous people, such as correrías, characterized the cycle of rubber extraction in the Putumayo region, nowadays Colombia (Chirif and Cornejo Chaparro 2009; Santos Granero and Barclay 2002; Taussig 1986). As a mode of labor force recruitment, correrías were a common practice of hunting indigenous men, women, and children who were captured by rubber traders, displaced, and forced to work in rubber camps (Pau 2019,44). Both state-sponsored colonization and rubber extraction have been economic processes that deeply affected the social and political lives of Ashaninka and Kukama Kukamiria, accentuating their exclusion and dispossession throughout the twentieth century (Espinosa 2016; Santos Granero and Barclay 1995).

The transformation of Junín as a defined regional space since the mid-twentieth century also led to the migration of people from the Andes who occupied the piedmont and interfluvial zones, displacing the Ashaninka and other ethnic groups to marginal areas with poorer soil quality and less availability of resources (Santos Granero 1996). The crystallization of central and periphery zones in Junín reflected the differentiated participation of indigenous people in economic and agricultural activities. Peripheral areas were characterized by increased commercial agriculture as the main form of production, whereas central areas also enabled their participation as wage labor. By the 1980s, the Ashaninka, for example, were directly involved in the market economy through wage labor, as independent farmers, or through engagement in the provision of services (Santos Granero 1996, 26-27). Although the development of extractive and productive activities exposed Ashaninka and Kukama Kukamiria peoples to the practices and values of the market economy, even as they acquired knowledge to participate as independent small-scale farmers (Santos Granero 1996), this has not been a symmetrical process. Subordination to local intermediaries and river merchants, as well as a lack of support from governmental institutions, has created multiple barriers for Ashaninka and Kukama Kukamiria populations

\footnotetext{
${ }^{7}$ For example, many cities and settlements in Loreto were actually created during the rubber extraction boom, between 1880 and 1914 (Agüero 1994, 69).
}

as they have adapted to inserting themselves in local markets and working against an exploitative economic system (Agüero 1994, 58; Santos Granero and Barclay 1995).

In the case of Loreto, it is also critical to consider the impact that the oil extraction process, which started in 1970, has had on Kukama Kukamiria communities. Even though it was promoted by the state in the beginning, private companies have taken a leading role in recent years. As in the past, oil extraction has also demanded the relocation of some Kukama Kukamiria to work as a labor force in urban settlements (Agüero 1994, 64).

One of the consequences of oil extraction that significantly impacts the Kukama Kukamiria is oil spills, which have repeatedly taken place in their territory. The first large oil spill in the low Marañón River basin took place in 2000 when 5,000 oil barrels of the Station 1-managed by the transnational company Pluspetrol-were spilled in the river. Another oil spill—also related to Pluspetrol—occurred in 2010, pouring 374 barrels into the river (Okamoto Mendoza 2011). A third spill took place in 2014 in the community of Cuninico (Fig. 2), located in Loreto, when the pipeline that moves the oil from the Amazon River to the coastal port broke and spilled 2,660 barrels (OEFA 2015, 11). In this case, the responsible entity was the national company PetroPerú.

While remediating these oil spills, both Pluspetrol and PetroPerú employed Kukama Kukamiria people who did not always receive basic protection to avoid contact with the oil. Besides the direct contamination of the rivers-which carry cultural, social, and economic value for the Kukama Kukamiria-the oil spills have also contributed to socioeconomic changes in the affected communities and have reinforced existing social and health inequalities. For example, although remediation jobs may have created more access to income, they have also influenced economic dynamics in the communities by transforming families' expected wage and decision-making responsibilities in the households, among other aspects. Communities affected by the oil spills have struggled to receive comprehensive healthcare treatment after being exposed to the contamination of the rivers, and no safety modifications to the pipeline to avoid future spills have been established.

To summarize, different waves of social and cultural changes brought by spontaneous and state-sponsored colonization projects as well as economic extractive activitiessuch as rubber and oil extraction-have deeply affected Ashaninka and Kukama Kukamiria communities. These processes have changed the communities' relations to markets, their livelihoods, and their economic strategies (Peralta and Kainer 2008; Santos Granero 1996; Santos Granero and Barclay 1995). Changes brought by colonialism and economic extractive cycles constitute a non-climatic factor that is key for understanding climate change vulnerability. In this 
situation, accessing the market becomes an adaptive strategy to face climate crises in a context where water and local food products are affected by pollution (Salick and Byg 2007, 15), but it also implies a history and various degrees of dependence and subordination, in which colonialism has played a crucial role.

\section{Vulnerability in indigenous communities in Junín and Loreto}

In this section, we discuss climate variability and vulnerability in Ashaninka and Kukama Kukamiria communities. The information is organized in three sections for purposes of clarity. First, we present a general view of exposure and sensitivity related to the Ashaninka and Kukama Kukamiria's experiences of seasonal variations, precipitations, and climatic events. Second, we focus on the sensitivity of their livelihoods considering the influence of non-climatic factors in agriculture and fishing. Finally, we explore different adaptive strategies and mechanisms that both groups use in response to challenges imposed by climate unpredictability and broader transformations in their territories.

\section{Exposure and sensitivity through indigenous experiences of environmental changes}

The weather was very different, now is very different (...). Now there is no summer, there is no winter. In the past, winter started by the end of February, I remember, and ended in May. But now it starts by the end of December, and ends in February, sometimes in March, and sometimes in June. (Indigenous leader from Cuninico, 50 years old, July 12, 2015)

As we discussed in the "Theoretical framework: vulnerable contexts, adaptation, and resilience" section, exposure and sensitivity are two key interconnected dimensions of vulnerability that we analyze in this section. Although interannual seasonal and precipitation variations are common in the Amazonian and Andean regions (Earls s/f; Gloor et al. 2013), estimations show that those variations are increasingly accompanied by unusual events which affect indigenous livelihoods and destabilize their productive activities. Communities are thus exposed to warming temperatures, high humidity, and extreme climatic events, such as more intense and more frequent flooding, extreme droughts, and unpredictable seasonality (Sherman et al. 2015, 2062; Zavaleta et al. 2018, 17).

In our research with Ashaninka and Kukama Kukamiria populations in Junín and Loreto respectively, indigenous narratives tended to underscore seasonality variations, changes in precipitation patterns, and changes in the frequency and intensity of floods. In relation to seasonality, most indigenous people still differentiate between two seasons, distinguished by the occurrence of precipitation (Espinosa 2019, 2020). In the case of Junín, the winter/wet season begins between September and October and lasts through March, when precipitation is normally expected to diminish. The summer season begins between April and May and lasts through October. In Loreto, the summer period begins between June and August. Although the Ashaninka and Kukama Kukamiria generally distinguish between these seasons, their narratives highlight how seasonality variations and their effects on certain ecological markers-such as precipitation patterns - are becoming unpredictable and difficult to anticipate.

Many interviewees indicated that the wet season had started unexpectedly early and was shorter. Likewise, they often did not associate precipitation with the "wet season," as they used to in the past, since now it occurs at different times throughout the year, with shorter duration and less intensity each time. Compared to the winter season, the summer season is said to have changed the most in recent years. In both Junín and Loreto, interviewees shared with us that summers are more intense than in the past:

The sun is stronger than before: today it burns us stronger. Before one could work, but now I cannot stand it. I cannot stand it. I go to work for a little while, the sun burns, you go looking for some shade. (Kukama Kukamiria woman from Atenas, 53 years old, July 6, 2015)

As this quote shows, the dry season is seen as more intense and with higher temperatures, affecting the amount of time spent working the farmland. Both Ashaninka and Kukama Kukamiria interviewees noted that the beginning of the summer season is also increasingly delayed, which is harmful for certain activities such as the preparation of the land for planting.

Variability of precipitation patterns, such as an excess of rain, is associated with an unusual rise in rivers' water levels and risks of flooding. In the case of Loreto, Atenas is located at a higher altitude and usually does not experience floods; however, in 2015, water from the river flooded some sectors of the village, including the school building. In the case of Cuninico, which is located at a lower level than Atenas, people also experienced drastic variability in water levels. In Junín region, most Ashaninka narratives emphasized that between 2005 and 2010, several bouts of intense precipitation increased the level of the Ene and Tambo rivers, flooding and affecting Potsoteni and Cheni villages. During those years, the stream closer to Potsoteni overflowed and flooded some sectors of the village. In the case of Cheni, the Tambo river flooded some farmlands located on the riverbank, including fields with cocoa and cassava crops. 
For many interviewees in Junín and Loreto, seasonal variability and changes in precipitation patterns and the occurrence of extreme climatic events are not new and recent events but rather have intensified over time. This coincides with the results of other studies on climate change and indigenous peoples in Amazonia (Fernández-Llamazares et al. 2014; Rengifo 2015).

\section{Sensitivity and indigenous livelihoods}

We have not reaped as expected in this little time, not as in the past. Suddenly, maybe is because of climate change that we reaped a small harvest (...) We have not sown other things more ourselves. Only bananas because we know that water is coming, why now? We have sown in high levels, but it still does not produce." (Kukama Kukamiria woman from Cuninico, 60 years old, May 4, 2016)

The vulnerability of the communities visited in Loreto and Junín is expressed in the sensitivity of their two main economic activities: agriculture, and fishing, which are crucial aspects of their livelihoods. As other studies have found, fish and bushmeat serve as primary proteins, while cassava and maize are important carbohydrates and sources of energy in an economic subsistence system (Sherman et al. 2015, 2051). In the communities studied, fishing and hunting have reduced in frequency and intensity because of the lack of fish and game close to the villages. In Junín, fishing and agriculture are complementary activities for household subsistence, while in Loreto both are main activities.

By itself, agriculture in the Amazon requires diversification of both crops and cultivation sites due to climate variability. This is also the case for the communities visited in Loreto and Junín. In both areas, the main crops are plantain, corn, cassava, and other vegetables and fruits. Although production is mainly for subsistence, what the family determines as an excess in production can be sold. In the case of Junín, cash crops are relevant for household economy, especially coffee and cocoa as they are sold at better prices.

The zones of production depend on the altitude, as certain crops, such as coffee, require certain conditions. In Loreto, village members also prefer to plant at different altitudes and areas according to availability. For example, in Cuninico, the plots in the communal islands are only available for production during the dry season.

It is important to mention that in all the villages, it is possible to purchase goods (vegetables, potatoes, noodles, rice, etc.) from local stores. The number of stores, however, depends on a variety of factors. In Cuninico, they increased after the oil spill to provide different processed goods. One interviewee (53 years old) told us: "When people from other areas knew that there had been a spill, they brought their business, and everything was very full." This process was also related to increased access to income from participating as wage laborers in the remediation of the oil spill area; however, this work also led to health issues due to a lack of protective equipment and subsequent oil exposure. These non-climatic factors exacerbate the effects of climatic variation, making access to food through agriculture much more strenuous and difficult to secure.

Exposure and sensitivity to climate variations such as extreme droughts and floods have a direct effect on household production. In both scenarios, subsistence and valuable cash crops are lost. In Cheni (Junín), flooding affected cocoa and cassava production, and in Loreto, one woman from Atenas mentioned:

Cassava is not good, it did not go well, many have lost and with other plants it was the same with the flood much has been lost, we could not sow the cassava, banana, peanut, or rice. Because of water, everything has flooded. (Kukama Kukamiria woman from Atenas, 54 years old, April 24, 2016)

In the communities of Loreto, the main problem was the general lack of food as the population used their reserves (animals and money) to purchase goods. As we mentioned in the previous section, there was a delay in the agricultural season, as people cannot start planting if the flood continues. Also, people in both communities in Loreto (Atenas and Cuninico) stated that they lost their crops because these rotted or dried out just before harvesting, and stored products were not enough to last throughout the whole flood season. ${ }^{8}$

Right now, we are zero, zero of food, we have no food. We have to buy from those who bring from the farms where it has not flooded, because nearby it has completely flooded and has taken 6 months and totally, already destroyed all the mashkis. ${ }^{9}$ (Kukama Kukamiria man from Cuninico, 53 years old, May 7 , 2016)

One person in Loreto also stated that floods have a moral effect on their lives: The negative results of production have reduced people's desire to plow in the same degree as they used to. Furthermore, the delay at the beginning

\footnotetext{
8 This situation is similar to the one experienced in other areas of the Amazon where crop failure is followed by the growing need for cash to buy resources or food that was previously grown for subsistence (Hofmeijer et al. 2013: 966; Zavaleta et al. 2018: 17), as in the case of extreme or unexpected floods. Floods nurture the beach and floodplains, but they can generate problems when they appear unexpectedly (e.g., when it starts raining during plantain or cassava production). Due to the sensitivity of these crops, highs amount of water do not allow them to grow (Rengifo 2015).

9 "Mashki" is the term usually used to refer to the small plantain logs plowed in the first step of production.
} 
of the summer season also seems to affect the raising of small livestock, because exposure to prolonged lower temperatures poses a major risk for these animals. Similarly, the prolonged winter season affects the availability of wild fruits and insects, which constitute another source of food and nutrients for some indigenous families.

At the same time, extreme droughts are also seen as negative, since all farm crops need water to survive, as we were told by community members from Cheni and Alto Camonashari (Junín). In fact, the increase of heat mentioned previously makes it difficult to sustain long working days as people experience heat exhaustion. ${ }^{10}$ According to Ashaninka interviewees, the sun is so bright that it burns the crops as well. The increase in daily average temperatures experienced by indigenous peoples influences the productivity of certain crops such as corn and coffee and has an impact on the families' capacity for food production and consumption, as has been identified in other cases as well (Fernández-Llamazares et al. 2014; Pérez Briceño 2018; Rengifo 2015).

The intensity of the dry season, perceived in both Junín and Loreto communities, also affects hunting and fishing activities, since the reduction of water levels in the streams drives small game further away from the villages and disrupts the reproduction cycle of different fish species. For these reasons, people in the different communities are reluctant to invest time in their farm plots as they fear the loss of their crops due to droughts or floods.

The second main economic activity in Junín and Loreto is fishing. This activity is particularly relevant in the case of Loreto, while marginal in the communities in Junín. In all locations, fishing is for subsistence purposes, although the excess can be sold or given to close relatives as a form of strengthening social networks. One exception is Cuninico (Loreto) where the population's main activity before the oil spill was to sell fish in other communities and cities, although this changed after the oil spill.

When I was 10 years old, we saw the fish in quantity.

(...). You went to the river and saw the fish walking.

Even we had some baskets carried by our parents

before. They put them in, they catch the fish. But now

it is not like that. It was worst when the spill happened.

(Kukama Kukamiria woman, 59 years old, July 23, 2015)

According to one Cuninico fisherman (57 years old), before the spill, they could obtain between 40 and 60 kilos of fish, but now they catch only between 5 to 10 kilos, and mostly smaller sized fishes than before.

\footnotetext{
10 This has also been identified in other studies with indigenous populations (Espinosa 2019, 2020; Hofmeijer et al. 2013, 966).
}

During the oil spill, there was no certainty that consuming fish did not pose a risk to their health, so fish could not be consumed. Additionally, the stigma of being from a village where the oil spill took place meant that people in other communities and cities avoided the fish sold by Cuninico fishermen. This example helps us to better understand the multi-scalar dimension of non-climatic factors. Even though the oil spill is the result of activities which are part of a national system of extraction involving transnational and national companies, it had direct consequences at the local level, including family dynamics and inter-communal interactions.

In the case of Ashaninka communities in Junín, fishing does not play a great role for subsistence and market economy as agriculture. In fact, fishing is increasingly becoming a sporadic and complementary activity. Any type of sale would be a surplus and only within the community. Despite this secondary role, community members in Junín perceive that the number of fish has decreased and that some species have disappeared. In Cheni, for example, it is hard to find doncella and sabalo, while in the communities of Loreto, it is almost impossible to find paiche.

In the case of Cheni, fishing was detrimentally impacted by a combination of urban population growth and extractive dynamics in the nearby city of Atalaya where people started overfishing, preventing the fish from crossing the river and completing their reproductive cycle. According to community members in Cheni, the frequent movement of boats has also caused fish to hide.

\section{Adaptation among Ashaninka and Kukama Kukamiria communities}

As we discussed in "Historical background: non-climatic factors shaping sensitivity and adaptation" section, livelihood strategies of Amazonian indigenous populations are influenced by their history and sociocultural experience at local, regional, and national scales (Santos Granero 1990, 413). Exposure and sensitivity of indigenous livelihoods to environmental changes are thus shaped by particular social, political, and historical processes, such as colonialism and how it transformed the relationship between indigenous and non-indigenous populations. In this section, we focus on another dimension of vulnerability: adaptive capacity.

Relevant adaptive capacities to consider are the diversification of the communal resource base, changes in the timing of production, new forms of market exchange, and changes in lifestyles and resource management. During times of climate variability and crisis, it is critical to promote and maintain biodiversity as indigenous peoples diversify their resource base. In Junín, families complemented agriculture with the breeding of small birds, temporary wage labor, or raising livestock. Moreover, 
birds have replaced bushmeat while hunting is declining. In Cheni, people living in the areas affected by flooding prefer to plant flood-resistant crops rather than less resistant ones. Although this strategy has a direct effect on the household economy, in general, diversifying helps to protect indigenous livelihoods from plagues that affect their crops and to minimize other risks (Fernández-Llamazares et al. 2014, 116; Rengifo 2015, 74; Salick and Byg 2007, 15-16; Sherman et al. 2015, 2051). As in other areas, the Ashaninka and Kukama Kukamiria plant different crops at different times of the year and in various locations (Berkes \& Jolly 2001 and Perreault 2005 in Fernández-Llamazares et al. 2014, 116). They choose to plant in less flood-prone areas so as to have a variety of options to harvest in the case of extreme weather conditions (Salick and Byg 2007, $15)$.

A second strategy observed in Cuninico (Loreto) is changes to agricultural timing along with the site of production. Crops located in flood-prone areas require earlier harvests, especially more sensitive crops such as cassava, papaya, or plantain. These areas are used for more resistant crops or others that do not take long to produce, such as rice, corn, and watermelon (Fernández-Llamazares et al. 2014, 116; Rengifo 2015, 69; Sherman et al. 2015, 2066).

While we were conducting fieldwork in Cuninico, we observed that people planted their crops in the stream to avoid losing the seeds. Then, when summer started, they would move the plants closer to the community. Others planned and prepared their plots earlier in the year so that they would ripe before winter. Another group decided to look for higher farmlands on which to plant their crops.

In relation to fishing, one adaptive strategy is diversification, which involves looking for fish in different areas. For example, after the oil spill in Cuninico, community members considered it necessary to go to lakes and streams further away to find fish that had not been contaminated by the oil. Because of this, people invested more time in obtaining good quality of fish that could be also sold. In the case of Junín, although the number of fish has declined, indigenous people have tried to adapt and develop new methods for fishing. This, however, has disrupted the reproductive cycle of some species, as indicated by some community members in Cheni.

Another adaptive strategy is to take part in market exchanges. In Junín, where fish and bushmeat are scarce, people buy goods in stores using the money that they obtain from cocoa and coffee production. Purchasing store goods implicates a change in diet patterns, as the products obtained are usually processed or canned. As previously explained, in Cuninico (Loreto), this practice increased after the oil spill. Analyses of recent events in Junín and Loreto show how the market as a primary exchange space has had an important historical role for both Ashaninka and Kukama Kukamiria ethnic groups. Besides market transactions through selling cash crops, exchange can also be manifested through acts of reciprocity or barter, involving the trading of goods between groups based on kin and socioeconomic ties (Salick and Byg 2007, 17, 21).

In Junín, where the flooding of the Tambo river basin occurs roughly every 5 years, the population has taken different measures to obtain goods. For example, a woman ( 28 years old) in Cheni told us that she and her family rescued the cassava and gave some of it away to her family and neighbors to avoid wasting it. Through this, they also secured access to cassava through their kin and friends' network at least for the next 3 months while new cassava grew.

As we addressed in the "Historical background: non-climatic factors shaping sensitivity and adaptation" section, it is important to note that the market has been part of historic and economic processes that have shaped indigenous communities not only in Peru but in different areas of South America. However, as in the communities that we visited, participation in the market has not meant forsaking subsistence practices or losing connection with the natural environment (Lu 2007, 597, 601). Despite the new opportunities that market exchange provides to Ashaninka communities and the central role of cocoa production in some villages, participation in the market has also become a source of concern and further ecological problems. In Junín, cocoa production is highly incentivized through regional development projects to replace other crops:

The Government has said 'do not sow coca [leaf], coca is bad but sow cocoa.' So, I will sow cocoa indiscriminately and I will cut down trees to sow cocoa and other plants indiscriminately? We have to be a little more responsible. The state has to be responsible for its projects according to the international standards of Climate Change, right? I think and it should be like that, right? (President of CART, July 19, 2016)

The promotion of cash crops such as cocoa clearly raises concerns about the problem of deforestation, which arises from the same projects that aim to provide indigenous communities with new sources of income. Such examples illustrate that it is necessary to consider the relevance of non-climatic factors and broader regional and national agricultural projects and programs along with climate change. Although such projects might not seem directly related to the latter, considered altogether, they allow us to better understand the connections between climatic and non-climatic factors.

In the case of fishing, some people try to compensate for reduced access to fish by purchasing goods like tuna, rice, and noodles which are becoming more common in family diets; other families try to diversify food by complementing processed goods with cassava or plantain.

Another adaptive strategy is the altered storage of food. This was an often-mentioned activity in Loreto. Fariña is an 
important technique for storing cassava in its dry and preserved form. The cassava is usually prepared yearly, before the rainy season, and replaces plantain as the main source of carbohydrates during those months (Sherman et al. 2015, 2066). Another option is to dry corn or to put the cassava underground where it can last longer without spoiling. It is also possible to preserve fish with salt; the duration of preservation depends on the species.

As we have discussed so far, the transformation of livelihoods does not depend solely on climate factors. Exposure, livelihood sensitivity, and adaptive strategies are shaped by different non-climatic factors as well. Companies operating in agriculture and extraction have local-level effects in community livelihoods, but their actions and investments also influence dynamics at the regional, national, and even transnational levels. In this sense, major non-climatic factors include deforestation and river contamination, which exist in both regions, and are associated with the scarcity of food resources. As we were told:

Trees have been cut down near the brooks and we are observing the effects, for example, now the rivers are drying out and the river snails are dying, how are they dying? Because when you cut down a tree, the sun reaches the water directly, and the [snail] eggs start to dry out and not reproduce anymore. (President of CART, July 19, 2016)

Similarly, contamination is another non-climatic driver common in both regions. In Junín, it is due to urban dynamics including extraction, stream contamination associated with inadequate residues management (Potsoteni), and with runoff waters from coffee production (Alto Camonashari). Other national and international companies also create sources of pollution, while in Loreto, contamination is primarily due to oil spills caused by transnational and national companies (Pluspetrol and PetroPerú respectively). In Junín, Repsol has also been exploring oil blocks. ${ }^{11}$

Finally, although they were not the focus of our research, changes in land use are important non-climatic factors (Zavaleta et al. 2018), as large-scale agriculture expands in the Amazonian region for different purposes like biofuel, coca leaf production, different types of economic integration (Sherman et al. 2015), or infrastructure and road construction (Hofmeijer et al. 2013; Sherman et al. 2015; Zavaleta et al. 2018). As we discussed in the "Theoretical framework: vulnerable contexts, adaptation, and resilience" and "Historical background: non-climatic factors shaping sensitivity and adaptation" sections, these factors are also related to the continuum of colonialist practices that shape economic

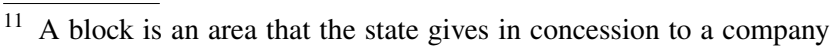
for oil exploration or exploitation.
}

activities, extraction, and even political action, as well as how indigenous people's vulnerability to environmental change is understood.

\section{Conclusions}

Building on what we described and discussed throughout this paper, we now return to the idea that vulnerability and its dimensions (exposure, sensitivity, and adaptive capacity) need to be understood in their heterogeneity, multiplicity, and complexity, as has been shown in other studies of indigenous peoples in Latin America (McNeish 2013; Soper 2019). As the cases of Ashaninka and Kukama Kukamiria communities show, livelihoods are becoming even more complex since they have been historically shaped by colonialism and extractive industries to various degrees. This requires an approach that takes into consideration the entanglements of livelihoods in contemporary contexts where non-climatic and climatic factors coexist and influence indigenous strategies, economic activities, and interests in and expectations for their livelihoods.

In relation to this, our paper concludes with two main points: (a) the relevance of addressing climate change vulnerability in multiple spatial and temporal scales and (b) the importance of acknowledging non-climatic factors as an integral part of a holistic analysis of this phenomenon.

Regarding exposure, seasonal variations, changes in precipitation, and extreme climatic events such as droughts and floods are among the most common manifestations of climate change reported by Amazonian indigenous people in other studies (Echeverri 2009). Our research with Kukama Kukamiria and Ashaninka populations also show that non-climatic factors, such as the colonial influence of extraction, have effects in the sensitivity of livelihoods just as morally and emotionally detrimental as climate change manifestations.

The convergence of climatic and non-climatic factors as multiple stressors (Sherman et al. 2015, 2052; Zavaleta et al. 2018, 3) allows us to emphasize how people live and experience both climatic manifestations and other socioeconomic, ecological, political, and cultural processes which affect their history and their communities. Thus, some changes in the exposure and sensitivity of their livelihoods are interpreted as a result of a variety of events or situations that have created a "disorder" in the use and accessibility of resources. For instance, as we have seen in both regions, people reported a decrease in the availability of fish, bushmeat, fruits and insects and experienced heat exhaustion and crop failure.

All these factors impact their livelihoods and the socioeconomic activities that sustain them. These environmental changes have also had an effect, triggering transformations 
in livelihoods and social dynamics in the communities, as well as the implementation of adaptive capacities such as diversification of crops (resistant to flood or with shorter production time), changes in time of production (early planting/harvesting), reciprocity and market exchange, and changes in lifestyles (dietary regimes) and resource management using mainly food storage mechanisms. These strategies demonstrate indigenous people's agency to plan, organize, and cope with these changes in scenarios where different private and public interventions have also transformed previous processes and outcomes of adaptation. In this regard, the cases of study analyzed in this paper provide examples of adaptation, and of a degree of resilience; they are flexible communities which adapt to the effects of climatic and nonclimatic factors. Nonetheless, they do not "bounce back" to a previous state, as some of these factors have been changing their structure and their adaptive mechanisms (Oliver-Smith 2013, 278). How long can they cope with these continuous stressors is a question that needs to be addressed through further research.

In Junín and Loreto, we focus on the different scales in which climate change, as a global phenomenon, has impacted regional and local areas. The qualitative approach used in this project also allows us to identify how people live and experience this global phenomenon and other processes that impact their communities. It invites us to understand how indigenous population feel and experience climate change, but also develop adaptive strategies in the process (Roncoli 2006 in Crate 2011, 176). Both regions show the "multilayered complexities" of local experiences around a global issue (Crate 2011, 175-177; Crate and Nuttall 2009, 394-395).

Paying close attention to multiple scales is useful for better understanding the global phenomenon of climate change, as well as how non-climatic factors are exacerbating its consequences. These factors include deforestation, river pollution due to oil spills, inappropriate urban residue management or runoff from coffee production, urban population growth, overfishing, and different types of development interventions. These different activities are shaped by colonialism and patterns of economic extraction (e.g., the expanding market economy, the rubber boom, and current globalization processes), which both regions have experienced over time. These extractive and commercial dynamics are part of these regions' environments, even as they enhance climate change and its consequences on indigenous people's livelihoods.

Finally, it is necessary to consider the interconnections and complexities caused by climatic and non-climatic factors (Crate and Nuttall 2016, 15) in contexts where economic growth and development are rooted in the exploitation of raw materials and extractive industries (Espinosa 2019, 2020; Ráez Luna 2019). As scholars analyzing vulnerability to climate change and disasters argue, underserved and poor communities are more vulnerable to these not because of their geographic location but due to structural factors such as poverty and racism which exacerbate the effects of climate change and disasters (Scheper-Hughes 2014, 220). In this scenario, climate change amelioration needs to address the role of these non-climatic factors in exacerbating the effects of climate change precisely because of the underlying neoliberal economic model. Thus, accounts of climate change that bring together analyses of local-global dynamics, socio-political context, indigenous knowledge, and lived experiences of communities can grasp more precisely the multilayered levels in which climate change vulnerability takes place. This becomes more crucial in the contemporary context shaped by the COVID-19 pandemic and the ways in which it has increased certain populations' vulnerability.

Table 1 Note: This data is mandatory. Please provide

\begin{tabular}{llll}
\hline Region & Province & District & Villages \\
\hline Loreto (high jungle) & Loreto & Urarinas & Cuninico \\
& & Parinari & Atenas \\
Junín (low jungle) & Satipo & Pangoa & Potsoteni \\
& & Mazamari & Alto Camonashari \\
& & Río Tambo & Cheni \\
\hline
\end{tabular}

\section{Appendix 1}

Table 1 and 2

Table 2 Note: This data is mandatory. Please provide

\begin{tabular}{llll}
\hline Region-villages & $\begin{array}{l}\text { Semi- } \\
\text { structured } \\
\text { interviews }\end{array}$ & Workshops $^{1}$ & $\begin{array}{l}\mathrm{N}^{\circ} \text { Households- } \\
\text { participant observa- } \\
\text { tion }\end{array}$ \\
\hline Loreto & $\mathbf{1 0 9}$ & $\mathbf{1 0}$ & $\mathbf{3 2}$ \\
Cuninico & 53 & 6 & 17 \\
Atenas & 56 & 4 & 15 \\
Junín & $\mathbf{5 9}$ & $\mathbf{4}$ & $\mathbf{6}$ \\
Potsoteni & 11 & 1 & - \\
Alto Camonashari & 5 & 2 & - \\
Cheni & 43 & 1 & 6 \\
Total & $\mathbf{1 6 8}$ & $\mathbf{1 4}$ & $\mathbf{3 8}$ \\
\hline
\end{tabular}

${ }^{1}$ The workshops included the elaboration of communal maps and ecological calendars 


\section{Appendix 2}

Acknowledgements The elaboration of this paper could not have been possible without the acceptance and help of the Ashaninka and Kukama Kukamiria indigenous organizations in Loreto and Junín: Huaynakana Kamatahuara Kana, Central Asháninka del Río Ene (CARE), and the Central Asháninka del Río Tambo (CART). We also want to specially acknowledge the families that welcome us into their houses and lives offering vital collaboration for our work.

Also, special thanks are given to the whole research team: first, the rest of the fieldwork team in both regions (Víctor Ramos Abenzur, Meredith Castro Ríos, Blanca Álvarez Becerra, Gabriela Gonzáles Malca, Roxana Gastelú Jiménez, and Guillermo Peláez Cotrina); second, Oscar Espinosa de Rivero who led the research process and Eduardo Pacheco Riquelme who helped with systematization; and finally, the support, comments, and suggestions of the Augustinians priests Manolo Berjón and Miguel Ángel Cadenas who have been crucial in the whole process.

Author contribution Both authors have been part of the literature review process, data systematization, and analysis. The first draft of the manuscript was written and commented by both authors, who also approved the final version. The only difference is that Dafne Lastra Landa has more knowledge about the Junín region and Claudia Grados Bueno of the Loreto region.

Funding This work was supported by Pontifical Catholic University of Peru (PUCP) under grant number 2015-3-0029 / 000000000000191.

\section{Declarations}

Conflict of interest The authors declare no competing interests.

\section{References}

Adger WN (2006) Vulnerability. Glob Environ Chang 16(3):268-281. https://doi.org/10.1016/j.gloenvcha.2006.02.006

Agüero O (1994) El milenio en la Amazonía Peruana: Mito y Utopía tupí - cocama o la subversión del orden simbólico. Abya Yala, CAAAP, Lima

Bebbington A (1999) Capitals and capabilities: a framework for analyzing peasant viability, rural livelihoods and poverty. World Dev 27(12):2021-2044. https://doi.org/10.1016/S0305-750X(99) 00104-7

Bebbington AJ, Batterbury SPJ (2001) Transnacional livelihoods and landscapes: political ecologist of globalization. Ecumene 8(4):369-380

Chirif A, Cornejo Chaparro M (2009) Imaginarios e imágenes de la época del caucho: Los sucesos del Putumayo. CAAAP, IWGIA, UPC, Lima

Cipolletti M (2017) Sociedades indígenas de la Alta Amazonía: fortunas y adversidades (siglos XVII-XX). Abya Yala, Quito

Crate SA (2011) Climate and culture: anthropology in the era of contemporary climate change. Annual Review of Anthropology 40:175-194. https://doi.org/10.1146/annurcv.anthro.012809. 104925

Crate SA, Nuttall M (2009) Epilogue: anthropology, science, and climate change policy. In: Anthropology and climate change: from encounters to actions. Left Coast Press, California, pp 394-400
Crate SA, Nuttall M (2016) Introduction: anthropology and climate change. In: Anthropology and climate change: from actions to transformations, 2nd edn. Routledge, London, New York, pp 9-27. https://doi.org/10.4324/9781315434773

Earls, J. (s/f). Inestabilidad y cambio climático en el Perú.

Echeverri JÁ (2009) Pueblos indígenas y cambio climático: el caso de la Amazonía colombiana. Bulletin de l'Institut français d'études andines 38(1):13-28. https://doi.org/10.4000/bifea.2774

Espinosa O (2016) Los asháninkas y la violencia de las correrías durante y después de la época del caucho. Bulletin de l'Institut français d'études andines 45(1):137-155. http://www.redalyc.org/ articulo.oa?id=12646877008

Espinosa O (2019) «No hay tiempo conforme»: Percepciones sobre el cambio climático en Comunidades indígenas de la Amazonía peruana. Espacio y Desarrollo, 33, 24. https://doi.org/10.18800/ espacioydesarrollo.201901.001

Espinosa O (2020) Los pueblos indígenas de la Amazonía peruana y el cambio climático: percepciones y propuestas. In: Salmón E (ed), Cambio climático y derechos humanos. Lima, pp 239-264

Espinosa O, Gonzales G, Amazonía T de (2014) Cambio climático y comunidades indígenas en la Amazonía peruana. In: Vila G, Damonte G (eds) Agenda de investigación en temas socioambientales en el Perú: una aproximación desde las ciencias sociales. CISEPA-PUCP, Lima, pp 153-192

Espinoza JC, Marengo JA, Ronchail J, Molina Carpio J, Noriega Flores L, Guyot JL (2014) The extreme 2014 flood in south-western Amazon basin: the role of tropical-subtropical South Atlantic SST gradient. Environ Res Lett 9(12):1-9. https://doi.org/10.1088/ 1748-9326/9/12/124007

Fernández-Llamazares Á, Díaz-Reviriego I, Méndez-López M, Sánchez IV, Pyhälä A, Reyes-García V (2014) Cambio climático y pueblos indígenas: Estudio de caso entre los Tsimane', Amazonia boliviana

Fundación Manuel J. Bustamante de la Fuente (2010) Cambio climático en el Perú: Amazonía. Fundación Manuel J. Bustamante de La Fuente, Lima

García Jordán P (2015) Cruz y arado, fusiles y discursos: la construcción de los Orientes en Perú y Bolivia, 1820-1940. Institut français d'études andines, Lima

Gloor M, Brienen RJW, Galbraith D, Feldpausch TR, Schöngart J, Guyot JL, Espinoza JC, Lloyd J, Phillips OL (2013) Intensification of the Amazon hydrological cycle over the last two decades. Geophys Res Lett 40(9):1729-1733. https://doi.org/10.1002/grl.50377

Hoffman S, Oliver-Smith A (2020) Introduction to the Second Edition of The Angry Earth:From Introduction to Widespread Reception. In: Oliver-Smith A, Hoffman S (eds) The Angry Earth. Disaster in Anthropological perspective. Routledge, London, New York, pp 1-14

Hofmeijer I, Ford JD, Berrang-Ford L, Zavaleta C, Carcamo C, Llanos E, Carhuaz C, Edge V, Lwasa S, Namanya D (2013) Community vulnerability to the health effects of climate change among indigenous populations in the Peruvian Amazon: a case study from Panaillo and Nuevo Progreso. Mitig Adapt Strat Glob Change 18(7):957-978. https://doi.org/10.1007/s11027-012-9402-6

Lu F (2007) Integration into the market among indigenous peoples: a cross-cultural perspective from the Ecuadorian Amazon. Curr Anthropol 48(4):593-602. https://doi.org/10.1086/519806

McNeish J-A (2013) Extraction, protest and indigeneity in Bolivia: the TIPNIS effect. Lat Am Caribb Ethn Stud 8(2):221-242. https:// doi.org/10.1080/17442222.2013.808495

Michetti M, Ghinoi S (2020) Climate-driven vulnerability and risk perception: implications for climate change adaptation in rural Mexico. J Environ Stud Sci 10(3):290-302. https://doi.org/10. 1007/s13412-020-00607-8

Ministry of Environment (2018) Mapa Nacional de Ecosistemas del Perú. Lima. https://cdn.www.gob.pe/uploads/document/file/ 
309735/Memoria_descriptiva_mapa_Nacional_de_Ecosistemas. pdf

O'Brien KL, Leichenko RM (2000) Double exposure: assessing the impacts of climate change within the context of economic globalization. Glob Environ Chang 10(3):221-232. https://doi.org/ 10.1016/S0959-3780(00)00021-2

O'Reilly J, Isenhour C, McElwee P, Orlove B (2020) Climate change: expanding anthropological possibilities. Annual Review of Anthropology 49:13-29. https://doi.org/10.1146/annur ev-anthro-010220

OEFA (2015) Cuninico, Informe Comunidad Nativa. 6. http://www. oefa.gob.pe/wp-content/uploads/2015/09/RES-844-2015-OEFADFSAI-COLORES.pdf

Okamoto Mendoza T (2011) Enclave extraction and unruly engagements: oil spills, contamination and the Cocama-Cocamilla indigenous people in the Peruvian Amazon. Dissertation, Norwegian University of Life Sciences

Oliver-Smith A (2013) Disaster risk reduction and climate change adaptation: the view from applied anthropology. Hum Organ 72(4):275-282

Orlove B (2009) The past, the present and some possible futures of adaptation. In: Adger WN, Lorenzoni I, O'Brien KL (eds) Adapting to climate change: thresholds, values, governance. Cambridge University Press, Cambridge, pp 131-163

Pau S (2019) Más antes, así era. Literaturas del caucho en la Amazonía peruana. Pakarina Ediciones, Lima

Pelling M (2011) Adaptation to Climate Change: From resilience to transformation. Routledge, London, New York

Peralta PA, Kainer KA (2008) Market integration and livelihood systems: a comparative case of three Asháninka villages in the Peruvian Amazon. J Sustain For 27(1-2):145-171. https://doi.org/10. 1080/10549810802225267

Pérez Briceño C-H (2018) Percepción y estrategias de adaptación al cambio climático de dos comunidades en la selva del Perú. Dissertation, Pontifical Catholic University of Peru

Ráez Luna E (2019) Cambio climático en el Perú: contribuciones nacionles, su definición y estado de avance. MOCICC, Lima

Rengifo G (2015) Cambio Climático: percepciones, consecuencias y Prácticas adaptativas en Comunidades indígenas Shipibo-Conibo y asháninkas (reserva Comunal el Sira). In: Merino M-I (ed) Adaptar nuestras vidas, mitigar los daños : desafíos del cambio climático. INTE PUCP, Lima, pp 61-76

Salick J, Byg A (2007) Indigenous Peoples and Climate Change. Tyndall Centre for Climate Change Research, Oxford

Santos Granero F (1990) Integración económica, identidad y estrategias indígenas en la Amazonía. In: Chirif A, Nelson M, Quijandría B (eds) Perú: el problema agrario en debate - SEPIA III. SEPIA, Lima, pp 399-419

Santos Granero F (1996) Introducción. In: Globalización y cambio en la amazonía indígena. Abya Yala, FLACSO, Cayambe, pp 8-43

Santos Granero F, Barclay F (1995) Modalidades de participación indígena en la economía regional. In: Órdenes y desórdenes en la selva central. Institut français d'études andines, Instituto de Estudios Peruanos, FLACSO, pp 276-308. https://doi.org/10. 4000/books.ifea. 2530
Santos Granero F, Barclay F (2002) La frontera domesticada: historia económica y social de Loreto 1850-2000. Fondo editorial de la PUCP, Lima

Scheper-Hughes N (2014) Katrina: The Disaster and its Doubles. In: Dove M (ed) The anthropology of climate change: an historical reader. Wiley Blackwell, Malden, Oxford pp 217-222

Sherman M, Ford J, Llanos-Cuentas A, Valdivia MJ, Bussalleu A (2015) Vulnerability and adaptive capacity of community food systems in the Peruvian Amazon: a case study from Panaillo. Nat Hazards 77(3):2049-2079. https://doi.org/10.1007/ s11069-015-1690-1

Solomon S, Qin M, Manning Z, Chen M, Marquis K-B, Tignor Averyt M, Miller H (2007) Summary for Policymakers. Climate Change 2007: the physical science basis. Contribution of Working Group I to the Fourth Assessment Report of the Intergovernmental Panel on Climate Change. Cambridge University Press, Cambridge. https://doi.org/10.1038/446727a

Soper R (2019) Livelihood interests, organizational discipline, and grassroots participation in Ecuadorian indigenous movement protests. Lat Am Caribb Ethn Stud 14(1):24-47. https://doi.org/ 10.1080/17442222.2019.1560610

Taussig M (1986) Shamanism, Colonialism, and the wild man: a study in terror and healing. The University of Chicago Press, Chicago, London

Tomasella J, Pinho P, Borma L, Marengo J, Nobre C, Bittencourt O, Prado M, Rodriguez D, Cuartas L (2013) The droughts of 1997 and 2005 in Amazonia: floodplain hydrology and its potential ecological and human impacts. Clim Change 116(3-4):723-746. https://doi.org/10.1007/s10584-012-0508-3

Whyte K (2017) Indigenous climate change studies: indigenizing futures, decolonizing the anthropocene. English Language Notes 55(1-2):153-162. https://doi.org/10.1215/00138282-55.1-2.153

Williams J (2012) The impact of climate change on indigenous people - the implications for the cultural, spiritual, economic and legal rights of indigenous people. International Journal of Human Rights 16(4):648-688. https://doi.org/10.1080/13642987.2011. 632135

Wilson NJ (2014) The politics of adaptation: subsistence livelihoods and vulnerability to climate change in the Koyukon Athabascan village of Ruby. Alaska Ecology 42(1):87-101. 10.1007/s

Zavaleta C, Berrang-Ford L, Ford J, Llanos-Cuentas A, Cárcamo C, Ross N-A, Lancha G, Sherman M, Harper S (2018) Multiple nonclimatic drivers of food insecurity reinforce climate change maladaptation trajectories among Peruvian Indigenous Shawi in the Amazon. PLoS ONE 13(10):1-30. https://doi.org/10.1371/journ al.pone. 0205714

Publisher's note Springer Nature remains neutral with regard to jurisdictional claims in published maps and institutional affiliations.

Springer Nature or its licensor (e.g. a society or other partner) holds exclusive rights to this article under a publishing agreement with the author(s) or other rightsholder(s); author self-archiving of the accepted manuscript version of this article is solely governed by the terms of such publishing agreement and applicable law. 